\title{
KREATIVITAS GURU DALAM MENINGKATKAN MOTIVASI BELAJAR PENDIDIKAN AGAMA ISLAM SISWA DI MTs N SUBULUSSALAM
}

\author{
Sabri ${ }^{1}$ \\ email: sabrikombih52@gmail.com
}

\begin{abstract}
ABSTRAK
Tujuan penelitian ini adalah untuk mengetahui bagaimana bentuk kreativitas guru dalam meningkatkan motivasi belajar pendidikan agama Islam siswa di MTsN Subulussalam, untuk mengetahui faktor yang menjadi hambatan dalam mengembangkan kreativitas dalam meningkatkan motivasi belajar pendidikan agama Islam siswa di MTsN Subulussalam, untuk mengetahui solusi yang diberikan terhadap hambatan kreativitas guru dalam meningkatkan motivasi belajar Pendidikan Agama Islam siswa di MTsN Subulussalam. Berdasarkanan alisis datanya, penelitian ini menggunakan pendekatan kualitatif. Penelitian ini bersifat deskriptif. Instrumen pengumpulan data yang digunakan dalam penelitian ini adalah observasi, wawancara, dan dokumentasi. Adapun responden dalam penelitian ini adalah guru. Dari penelitian yang dilakukan diperoleh kesimpulan bahwa: 1) bentuk-bentuk kreativitas guru yang dilakukan di MTsN Subulussalam ialah membangkitkan motivasi dan perhatian anak, memperhatikan perbedaan karakteristik anak, pengelolaan kelas, pengulangan, pemberian hadiah, memberikan pujian, mengadakan tanya jawab, menggunakan alat peraga, menyanyikan lagu, guru yang penggembira, interaksi antara guru dengan siswa, penugasan yang diberikan oleh guru, guru mengembangkan sumber belajar, persaingan atau kompetensi. 2) Faktor-faktor yang mempengaruhi kreativitas guru dalam meningkatkan motivasi belajar siswayaitu: Kedisiplinan Siswa, Tingkat Pendidikan, Fasilitas, Guru merasa puas dengan pembelajaran yang dilaksanakan. 3) Solusi yang diberikan terhadap hambatan kreativitas guru dalam meningkatkan motivasi belajar Pendidikan Agama Islam siswa ialah memberikan hukuman, mencari tempat kos, guru bekerja sama dalam menciptakan kreativitas yang baru, meningkatkatkan fasilitas, meningkatkan fungsi komite sekolah yang jujur, meningkatkan wawasan guru dengan mengikuti program Musyawarah Guru Mata Pelajaran.
\end{abstract}

\section{Kata Kunci: Kreativitas Guru dan Motivasi Belajar}

\begin{abstract}
The purpose of this study is to find out how the form of teacher creativity in increasing the motivation to learn Islamic religious education of students in MTsN Subulussalam, to find out the factors that are obstacles in developing creativity in increasing motivation to learn Islamic religious education of students in MTsN Subulussalam, to find out the solutions given to obstacles teacher creativity in increasing motivation to learn Islamic Religious Education
\end{abstract}

${ }^{1}$ Dosen Institut Pendidikan Tapanuli Selatan 
students at MTsN Subulussalam. Based on the data analysis, this study uses a qualitative approach. This research is descriptive. Data collection instruments used in this study were observation, interviews, and documentation. The respondents in this study were teachers. From the research conducted it was concluded that: 1) the forms of teacher creativity carried out at MTsN Subulussalam are arousing children's motivation and attention, paying attention to differences in children's characteristics, classroom management, repetition, giving gifts, giving praise, holding questions and answers, using teaching aids , singing songs, cheerful teachers, interactions between teachers and students, assignments given by teachers, teachers developing learning resources, competition or competence. 2) Factors that influence the creativity of teachers in increasing student learning motivation are: Student Discipline, Education Level, Facilities, Teachers feel satisfied with the learning carried out. 3) The solution given to the obstacles of teacher creativity in increasing students' motivation to learn Islamic Religious Education is to provide penalties, find boarding houses, teachers work together in creating new creativity, improve facilities, improve the functioning of honest school committees, increase teacher insight by following the program Teacher Subject Meeting.

\section{Keywords: Teacher Creativity and Learning Motivation}

\section{PENDAHULUAN}

Kreativitas pembelajaran guru seringkali menjadi topik perbincangan berbagai pihak, karena dinilai menentukan pencapaian hasil pendidikan. Guru merupakan ujung tombak berlangsungnya kegiatan pembelajaran, sehingga memiliki peran dan fungsi penting sebagai sumber belajar dan bahkan kerap kali mendominasi proses transformasi nilai ilmu pengetahuan kepada peserta didik. Dugaan yang ada, kemampuan guru akan menghasilkan pembentukan kualitas peserta didiknya. Namun mungkin saja penguasaan guru terhadap bahan ajar atau materi pelajaran yang diberikan sudah cukup memadai, tetapi kurang mampu mengemasnya dalam pembelajaran, kurang kreatif, menoton, membosankan, kurang menarik dan lain sebagainya, akhirnya berujung dengan pencapaian hasil pendidikan yang kurang memadai.

Kreativitas merupakan kapasitas untuk membuat hal baru. Jadi orang yang kreatif adalah orang yang berfikir dan bertindak mengubah suatu ranah atau menetapkan suatu ranah baru. Jadi bisa disimpulkan bahwa kreativitas adalah kemampuan memunculkan dan mengembangkan gagasan baru, ide baru sebagai pengembangan dari ide yang lahir sebelumnya serta memecahkan masalah yang dihadapi.

Kreativitas seorang guru sangat penting, karena untuk menjadi seorang guru yang profesional guru harus memiliki kemampuan dan keahlian dalam bidang keguruan dan mampu 
melakukan tugas dan fungsinya sebagai guru dengan kemampuan yang maksimal. Guru sebagai komponen pendidikan dan pengajaran berperan besar dalam keberhasilan belajar mengajar. Tugas ini menjadi tanggung jawab guru mengantarkan peserta didik kepada tingkat kedewasaan.

Kreativitas dapat dipandang sebagai proses berpikir tentang berbagai macam gagasan atau pemecahan masalah yang hendak dilakukan oleh seseorang. Dengan demikian kreativitas guru sangat diharapkan untuk membangkitkan aktivitas anak dalam belajar. ${ }^{2}$ Salah satu bentuk kreativitas yang mesti dimiliki oleh guru yaitu metode pembelajaran.

Namun realitanya peserta didik sering kali gagal mengikuti proses belajar mengajar karena guru kurang kreatif dalam proses belajar mengajar sehingga peserta didik bosan dan kurang senang dalam belajar. Akibatnya, penjelasan guru sukar dipahami, penjelasan guru tidak fokus pada masalah yang disampaikan, kurang kreativitas dalam proses belajar mengajar. Sehingga peserta didik bosan dan mengantuk dalam belajar sehingga berakibat tujuan belajar tidak tercapai.

Guru yang bijaksana tentu sadar bahwa kebosanan dan kelelahan anak didik salah satunya adalah berpangkal dari penjelasan guru yang tidak fokus pada masalah yang disampaikan. Jika guru tidak memiliki kemampuan untuk menjelaskan materi dengan baik. Guru harus berusaha untuk memiliki ilmu pengetahuan yang luas atau mampu menciptakan sesuatu yang baru dalam mengajar guna untuk mencapai tujuan pendidikan. Kreativitas dapat dipandang sebagai proses berpikir tentang berbagai macam gagasan atau pemecahan masalah yang hendak dilakukan oleh seseorang. Dengan demikian kreativitas guru sangat diharapkan untuk membangkitkan aktivitas anak dalam belajar. $^{3}$

Dari pemaparan konteks di atas, penulis juga menemukan beberapa masalah mengenai kreativitas guru dalam proses pembelajaran, salah satu diantaranya adalah guru belum menggunakan metode pembelajaran yang kreatif. Menurut Slameto, Metode mengajar yang digunakan guru dalam proses pembelajaran berpengaruh terhadap motivasi belajar. Metode mengajar guru yang kurang baik akan mempengaruhi belajar siswa yang tidak baik pula. Metode mengajar yang kurang baik itu dapat terjadi misalnya karena guru kurang persiapan dan kurang

${ }^{2}$ Tarmizi Situmorang,Mengembangkan Potensi Kreativitas Anak Dalam Belajar, Al-Rasyidin ed., Pendidikan dan Psikologi Islam (Bandung: Cita Pustaka Media, 2000), h. 68.

${ }^{3}$ Ibid. 
menguasai bahan pelajaran sehingga guru tersebut menyajikannya tidak baik, sehingga siswa kurang senang terhadap pelajaran atau gurunya. ${ }^{4}$

Kurangnya ketertarikan siswa terhadap materi pembelajaran yang diberikan oleh guru disebabkan karena guru mengajar hanya menggunakan metode mencatat buku saja tanpa menerangkan materinya, sehingga siswa bosan dalam proses pembelajaran. Dijelaskan dalam buku Iskandar Agung bahwa guru itu perlu memberikan pengajaran secara menarik agar peserta didik lebih bergairah untuk menjalankan proses belajar. Untuk itu guru perlu menggunakan metode pembelajaran yang variatif dan sesuai dengan kebutuhan, sehingga proses pembelajaran tidak berjalan kaku, searah dan membosankan siswa/peserta didik. ${ }^{5}$

Hal ini penting untuk menciptakan pembelajaran yang dapat meningkatkan motivasi para siswa. Penggunaan metode yang tepat akan turut menentukan efektivitas dan efisiensi pembelajaran. Seorang guru harus melakukan pemilihan dan penentuan metode yang sesuai dengan tujuan pembelajaran yang telah dirumuskan. Selain penggunaan berbagai metode yang tepat, perlu adanya pemberian motivasi kepada siswa, sehingga dengan diberikannya motivasi kepada siswa, diharapkan proses pembelajaran dapat berhasil. ${ }^{6}$

Berdasarkan hasil pengamatan di MTsN Subulussalam guru dalam mengajar menggunakan metode mencatat buku. Akan tetapi guru selalu menerangkan materinya. Sehingga siswa tidak jenuh dan bosan dalam pembelajaran. memberikan variasi juga dalam bentuk pembelajaran misalnya dalam bentuk belajar di aula dengan model belajar bersama, akan tetapi siswa yang sudah bisa maka dibedakan dalam kelompok yang tidak sama, sehingga ada lokal 1 dan lokal 2 sekitar 27 orang. $^{7}$

Guru memberikan pengajaran secara menarik sehingga siswa bergairah untuk menjalankan pembelajaran. Guru menggunakan metode pembelajaran yang variatif dan sesuai dengan kebutuhan siswa. Kemudian adanya perhatian dari guru dan adanya penghargaan terhadap siswa. Misalnya dalam mengerjakan tugas sekolah guru selalu memeriksa tugas siswa

\footnotetext{
${ }^{4}$ Slameto, Belajar dan Faktor-faktor yang Mempengaruhinya (Jakarta: Rineka Cipta, 2003), h. 65.

${ }^{5}$ Iskandar Agung, Meningkatkan Kreativitas Pembelajaran Bagi Guru (Jakarta: Bestari Buana Murni, 2010), h. 60.

${ }^{6}$ Abdul Mujib dan Yusuf Muzdakkir, Nuansa-Nuansa Psikologi Islam (Jakarta: PT. Grafindo Persada, 2009), h. 243.

${ }^{7}$ Observasi, di MTs N Subulussalam, Tanggal 3 Maret 2017.
} 
tersebut dan memberikan hadiah kepada siswa yang berprestasi dalam pembelajaran pendiddikan agama Islam. Sehingga siswa termotivasi dalam pembelajaran agama Islam. ${ }^{8}$

\section{METODE PENELITIAN}

Berdasarkan analisis data, penelitian ini menggunakan pendekatan kualitatif yaitu penelitian yang dilakukan dengan mengamati keadaan sekitarnya dan menganalisisnya dengan menggunakan logika ilmiah. ${ }^{9}$ Penelitian ini menggunakan metode deskriptif yakni penelitian yang menggambarkan objek sesuai apa adanya. ${ }^{10}$ Metode deskriptif berusaha untuk menggambarkan objek atau subjek yang diteliti sesuai dengan apa adanya, dengan tujuan menggambarkan secara sistematis fakta dan karakteristik objek yang diteliti secara tepat. ${ }^{11}$ Pendekatan ini digunakan untuk menggambarkan kreativitas guru dalam meningkatkan motivasi belajar pendidikan agama Islam siswa di

Sumber data yang dibutuhkan dalam penelitian ini ada dua jenis, yaitu:

a. Sumber data primer yaitu data pokok yang dibutuhkan dalam penelitian ini, yaitu Guru Pendidikan Agama Islam di MTs N Subulussalam

b. Sumber data sekunder yaitu guru, dan Siswa di MTs N Subulussalam

Penelitian ini adalah penelitian kualitatif yang menjadi instrument pengumpulan data adalah:

a. Observasi adalah suatu pengamatan langsung pada lokasi penelitian

b. Wawancara yaitu melaksanakan wawancara langsung dengan sumber data, yaitu Guru yang berjumlah 4 orang Pendidikan Agama Islam di MTs N Subulussalam

c. Mengadakan studi dokumentasi terhadap data yang di perlukan di lapangan.

${ }^{8}$ Observasi, di MTs N Subulussalam, Tanggal 5 Maret 2017.

${ }^{9}$ Sugiyono, Metode Penelitian Kualitatif, Kuantitatif dan R\&D (Bandung: Alfabeta, 2009), h. 8.

${ }^{10}$ Sukardi, Metodologi Penelitian Pendidikan: Kompetensi dan Praktiknya (Jakarta: Bumi Aksara, 2003), h. 157.

${ }^{11}$ Hamid Darmadi, Metode Penelitian Pendidikan (Bandung: Alfabeta, 2011), h. 151. 


\section{HASIL PENELITIAN}

\section{Kreativitas Guru-guru Dalam Meningkatkan Motivasi Belajar Siswa di MTs N} Subulussalam

Adapun kreativitas guru dalam meningkatkan motivasi belajar siswa MTs N Subulussalam adalah sebagai berikut:

a. Membangkitkan motivasi dan perhatian anak

Untuk membangkitkan minat belajar bagi siswa dapat dilakukan dengan cara motivasi ekstrinsik seperti; pemutaran film yang dilakukan di dalam kelas seperti sejarah-sejarah nabi yang dapat di pahami oleh siswa. Karya wisata diberikan kepada siswa dengan mengajak siswa rekreasi agar siswa tidak bosan dalam pembelajaran agama Islam. Guru merefleksi siswa yaitu melihat diri mereka sendiri dan menentukan kekuatan dan kelemahan mereka sendiri, tulis nama siswa di papan tulis yakni siswa merasa istimewa adalah dengan menuliskan namanya di papan tullis dan menggambarkan bintang di sebelahnya. Dengan adanya motivasi dan perhatian yang dilakukan oleh peserta didik dalam belajar, maka materi yang disampaikan oleh pendidik akan mudah dipahami oleh peserta didik. Selain itu, tujuan pembelajaran akan tercapai.

b. Memperhatikan perbedaan karakteristik anak

Guru dapat mengoptimalkan suasana kelas dan dan suasana belajar yang lebih kondusif dengan memahami karakteristik pada siswa. Agar proses belajar mengajar dapat berjalan dengan baik dan juga agar materi yang disampaikan oleh guru dapat di pahami oleh anak-anak. Dengan adanya pemahaman terhadap karekteristik siswa maka seorang guru sudah paham dengan masing-masing siswanya, agar tujuan pembelajaran dapat tercapai sebagaimana mestinya.

c. Pengelolaan Kelas

1. Pengaturan tempat duduk

2. Penataan Keindahan ruangan dan kebersihan kelas

d. Penggunaan metode

e. Pemberian hadiah

f. Memberikan pujian

g. Mengadakan tanya jawab 
h. Menggunakan alat peraga

i. Menyayikan lagu

j. Guru yang penggembira

k. Interaksi antara Guru dengan Siswa

1. Penugasan yang di berikan oleh guru

m. Pembelajaran yang Menyenangkan di Luar Kelas atau Alam

n. Guru mengembangkan Sumber Belajar

o. Persaingan atau Kompetensi

\section{Faktor-faktor yang Menjadi hambatan dalam pengembangan Kreativitas Guru dalam Meningkatkan Motivasi Belajar Siswa di MTs N Subulussalam}

Berdasarkan hasil wawancara peneliti di MTs N Subulussalam ada faktor yang menjadi hambatan dalam pengembangan kreativitas guru dalam meningkatkan motivasi belajar siswa yaitu:

a. Kedisiplinan Siswa

Dari data yang diperoleh di lapangan peneliti melihat bahwa kedisiplinan siswa memang masih sedikit sehingga sangat berpengaruh terhadap kreativitas guru, karena kedisiplinan adalah hal yang sangat penting dalam mencapai segala hal, akan tetapi itu merupakan sesuatu yang bisa diatasi oleh gurunya dengan memberikan hukuman bagi mereka yang sering terlambat. Dengan membersihkan lapangan sekolah dan ruangan guru.

b. Tingkat Pendidikan

Tingkat pendidikan juga sangat berpengaruh terhadap berkembangnya kreativitas, semakin tinggi pendidikan maka semakin tinggi pula kreativitas yang dimiliki. Dari data yang diperoleh di lapangan peneliti melihat bahwa jenjang pendidikan sangat mempengaruhi kreativitas guru, karena kreativitas adalah merrupakan kemampuan untuk menemukan dan memunculkan ide-ide baru guna menciptakan proses belajar mengajar yang baik, dari hal tersebut tingkat pendidikan dapat mempengaruhi kreativitas guru terutama dalam meningkatkan motivasi belajar pendidikan agama Islam siswa terhadap materi yang telah disampaikan oleh guru. 
c. Usia

Dari data yang diperoleh dapat peneliti simpulkan bahwa guru di MTs N Subulussalam memiliki kreativitas yang baik. Dan semua ini dapat menunjang kreativitas guru dalam meningkatkan motivasi belajar siswa dalam proses pembelajaran yang berlangsung.

d. Fasilitas

Dalam proses belajar mengajar akan berjalan lancar kalau di dukung oleh sarana yang lengkap, karena fasilitas merupakan masalah yang urgen dalam pendidikan, maka dalam pembaharuan pendidikan kita harus memperbaharui mulai dari gedung sekolah sampai kepada alat peraga. Tersedianya fasilitas yang banyak akan menambah pengetahuan dan wawasan sehingga dapat memunculkan berfikir kreatif.

e. Guru merasa puas dengan pembelajaran yang dilaksanakan

Dari data yang diperoleh di lapangan peneliti melihat bahwa guru di MTs N Subulussalam memang sudah puas dengan pembelajaran yang di laksanakan sehingga mereka selalu berharap kalau siswanya tidak pernah bosan dengan apa yang diajarkan dan mampu mengamalkan ibadah yang telah disampaikan oleh guru kepada mereka.

f. Guru Kurang Percaya Diri

Berdasarkan wawancara peneliti dengan Ibu Minta menjelaskan bahwa salah satu faktor yang mempengaruhi kreativitas guru dalam meningkatkan motivasi belajar pendidikan agama Islam siswa yaitu kurang percaya diri, dalam hal ini susah dalam menyampaikan materi sehingga yang ingin disampaikan tidak tersampaikan semaksimal mungkin sehingga proses pembelajaran tidak berlangsung dengan baik.

\section{Solusi yang diberikan guru terhadap hambatan kreativitas dalam meningkatkan} motivasi belajar siswa di MTs N Subulussalam

a. Kedisiplinan Siswa merupakan salah satu faktor penghambat kreativitas guru di sekolah. Adapun solusi yang dapat di berikan oleh guru bagi siswa yang tidak mentaati kedisiplinan adalah dengan mendata siswa yang terlambat dan memprosesnya dan mengambil tindakan selanjutnya (hukuman), bagi siswa yang terlambat dikarenakan jarak yang jauh antara rumah dan sekolah maka solusi yang dapat diberikan ialah mencari tempat kos bagi siswa. 
b. Tingkat pendidikan dan usia juga merupkan salah satu faktor yang mempengaruhi kreativitas guru. Tingkat pendidikan dan usia yang berbeda bagi tiap guru dapat menimbulkan kreativitas guru yang berbeda-beda. Adapun solusi yang dapat dilakukan pada tingkat pendidikan dan usia guru yang berbeda-beda ialah para guru juga dituntut untuk saling bekerja sama dalam menciptakan kreativitas yang baru. Karena apabila ditinjau dari segi umur mereka yang saling berdekatan. Sehingga antara keduanya berkomunikasi dan saling memahami agar lebih baik dalam mengembangkan kreativitas yang baru.

c. Fasilitas. Solusi yang diberikan agar fasilitas sekolah dapat memadai ialah meningkatkan fungsi keberadaan komite sekolah yang jujur, independen, serta trasparan sebagai pihak yang mengawasi kecurangan yang dilakukan oleh pemerintah daerah maupun pihak sekolah. Karena dalam pemerataan fasilitas di sekolah masih banyak membutuhkan bantuan dari berbagai pihak, baik itu dari pemerintahan pusat, pemerintahan daerah, maupun pihak-pihak sekolah.

d. Guru merasa kurang puas dengan pembelajaran yang dilaksanakan. Solusi yang dapat diberikan ialah guru dapat meningkatkan wawasan yang berkaitan dengan pembelajaran yakni mengikuti program MGMP (Muyawarah Guru Mata Pelajaran) hal ini bertujuan untuk memperoleh informasi edukatif yang berkaitan dengan ilmu pengetahuan dan tekhnologi, kegiatan kurikulum, metodologi, serta dapat meningkatkan dan keterampilan dalam merencanakan, melaksanakan dan membuat evaluasi program pembelajaran.

e. Guru kurang percaya diri. Solusi yang diberikan agar guru percaya diri dalam memberikan pembelajaran ialah bahwa seorang guru tidak boleh merasa takut dan tidak percaya diri dari segi hal apapun baik ketika pembelajaran berlangsung. Karena itu akan menghilangkan martabat seorang guru dalam membina generasi bangsa, karena guru adalah sebagai contoh atau tauladan yang baik bagi murid, oleh karena itu guru harus percaya diri dengan sepenuh hati dalam proses pembelajaran berlangsung dan juga ketika menyampaikan materi yang diajarkan sehingga dengan demikian materi yang sudah diajarkan anak-anak menjadi paham. 


\section{PEMBAHASAN HASIL PENELITIAN}

Berdasarkan hasil penelitian, diketahui bahwa kreativitas guru dalam meningkatkan motivasi belajar pendidikan agama Islam siswa MTs N Subulussalam dapat dikatakan sangat baik. Karena cara guru dalam meningkatkan motivasi belajar pendidikan agama Islam MTs $\mathrm{N}$ Subulussalam begitu bervariasi. Yakni guru telah menggunakan beberapa cara dengan kreatifnya guru yang bertujuan agar dapat membuat proses pembelajaran dapat berjalan dengan lancar dan tidak membosankan. Hal ini sejalan dengan apa yang di jelaskan dalam buku yang berjudul meningkatkan pembelajaran bagi guru karangan Iskandar Agung, yang berisikan bahwa seorang guru perlu memberikan pengajaran secara menarik agar anak didik lebih bergairah dalam proses berlangsungnya pembelajaran.

Oleh karena itu guru di MTs N Subulussalam dalam proses belajar mengajar mengupayakan dengan kreatif bagaimana agar pembelajaran tersebut berjalan dengan lancar dan baik sesuai dengan tujuan yang diharapkan baik dari segi guru maupun dari segi peserta didiknya. Dalam proses belajar mengajar guru di MTs N Subulussalam berupaya agar pembelajaran dapat berlangsung dengan baik dan juga dapat tersampaikan dengan baik. Supaya anak didik benar-benar paham dan mengetahui tentang materi yang telah disampaikan oleh guru.

Adapun cara kreatif yang dilakukan oleh guru dalam pembelajaran yaitu pemberian hadiah. Dimana dalam pembelajaran guru terus memperhatikan bagaimana kondisi anak didik dan juga kondisi kelas saat pembelajaran berlangsung disaat anak-anak merasa bosan dan jenuh di dalam kelas saat proses belajar berlangsung. Guru mencari cara bagaimana agar perhatian anak teralihkan kepada materi yang disampaikan guru dengan cara pemberian hadiah. Seperti memberikan buku tulis atau pena dengan tujuan sebagai penarik memotivasi anak. Selain itu guru juga terus mengadakan pengulangan terhadap materi yang sudah diajarkan sebelum menyampaikan materi selanjutnya yang akan disampaikan karena jika terus diulang-ulang maka anak semakin mudah untuk mengingat materi yang diajarkan.

Abdul Rahman Shaleh menjelaskan bahwa dalam upaya mengingat apa yang telah dipelajari perlu usaha-usaha yaitu dengan cara pengulangan. Dan guru dalam pembelajaran juga harus menguasai bahan pelajaran dan mampu menggunakan metode yang bervariasi dan cocok terhadap materi yang akan disampaikan guru agar dapat dipahami anak dengan baik. Selain itu 
dalam meningkatkan motivasi belajar pendidikan agama Islam siswa guru memperhatikan perbedaan anak didik, memberikan perhatian terhadap anak dalam proses belajar mengajar agar anak tertarik dan senang materi yang disampaikan oleh guru. Selain itu juga untuk meningkatkan motivasi belajar pendidikan agama Islam siswa guru menggunakan cara kreatif lainnya yaitu, menggunakan alat peraga, menyanyikan lagu, mengadakan tanya jawab, interaksi antara guru dengan siswa dan pembelajaran yang menyenangkan di luar kelas atau alam dengan kreatif. Sehingga dengan kreatif yang dilakukan guru dalam proses belajar mengajar tujuan yang diharapkan dapat tercapai dengan baik baik dari segi guru maupun anak didik.

Kreativitas guru dalam meningkatkan motivasi belajar pendidikan agama Islam tidak terlepas dari faktor-faktor yang mempengaruhi kreativitas guru dalam meningkatkan motivasi belajar pendidikan agama Islam siswa yaitu, dari faktor kedisiplinan siswa, tingkat pendidikan, usia, fasilitas, guru puas dengan pembelajaran yang dilaksanakan, dan guru kurang percaya diri dalam menyampaikan pelajaran kepada peserta didik.

Adapun Solusi yang diberikan terhadap hambatan kreativitas guru dalam meningkatkan motivasi belajar Pendidikan Agama Islam siswa di MTs N Subulussalam ialah memberikan hukuman bagi siswa yang tidak mematuhi peraturan, bagi siswa yang terlambat dikarenakan jarak yang jauh antara rumah dan sekolah maka solusi yang dapat diberikan ialah mencari tempat kos bagi siswa. Adapun solusi yang dapat dilakukan pada tingkat pendidikan dan usia guru yang berbeda-beda ialah para guru juga dituntut untuk saling bekerja sama dalam menciptakan kreativitas yang baru. Sehingga antara keduanya berkomunikasi dan saling memahami agar lebih baik dalam mengembangkan kreativitas yang baru.

Solusi yang diberikan agar fasilitas sekolah dapat memadai ialah meningkatkan fungsi keberadaan komite sekolah yang jujur, independen, serta transparan sebagai pihak yang mengawasi kecurangan yang dilakukan oleh pemerintah daerah maupun pihak sekolah. Guru merasa kurang puas dengan pemelajaran yang dilaksanakan, solusi yang dapat diberikan ialah guru dapat meningkatkan wawasan yang berkaitan dengan pembelajaran yakni mengikuti program MGMP (Muyawarah Guru Mata Pelajaran) Solusi yang diberikan agar guru percaya diri dalam memberika pembelajaran ialah bahwa seorang guru tidak boleh merasa takut dan tidak percaya diri dari segi hal apapun baik ketika pembelajaran berlangsung. Karena itu akan menghilangkan martabat seorang guru dalam membina generasi bangsa. 


\section{KESIMPULAN}

Berdasarkan hasilpenelitian dan pembahasan yang telah dilakukan terhadap kreativitas guru dalam meningkatkan motivasi belajar pendidikan agama Islam siswa MTs N Subulussalam, maka dapat dikemukakan beberapa kesimpulan sebagai berikut.

1. Adapun bentuk-bentuk kreativitas guru yang dilakukan di MTs N Subulussalam ialah membangkitkan motivasi dan perhatian anak, memperhatikan perbedaan karakteristik anak, pengaturan tempat duduk, penataan keindahan ruangan dan kebersihan kelas, pengulangan, penggunaan metode, pemberian hadiah, memberikan pujian, mengadakan tanya jawab, menggunakan alat peraga, menyanyikan lagu, guru yang penggembira, interaksi antara guru dengan siswa, penugasan yang diberikan oleh guru, pembelajaran yang menyenangkan di luar kelas atau alam, guru mengembangkan sumber belajar, persaingan atau kompetensi.

2. Faktor-faktor yang Mempengaruhi Kreativitas Guru dalam Meningkatkan Motivasi Belajar Siswa MTs N Subulussalam yaitu: Kedisiplinan Siswa, Tingkat Pendidikan, Fasilitas, Guru merasa puas dengan pembelajaran yang dilaksanakan. Dengan kreativitas guru dalam meningkatkan motivasi belajar pendidikan agama Islam siswa sehingga hasil pembelajaran yang dilakukan guru dapat tercapai dengan baik.

3. Adapun Solusi yang diberikan terhadap hambatan kreativitas guru dalam meningkatkan motivasi belajar Pendidikan Agama Islam siswa di MTs N Subulussalam ialah memberikan hukuman, bagi siswa yang terlambat dikarenakan jarak yang jauh antara rumah dan sekolah maka solusi yang dapat diberikan ialah mencari tempat kos bagi siswa. Adapun solusi yang dapat dilakukan pada tingkat pendidikan dan usia guru yang berbeda-beda ialah para guru juga dituntut untuk saling bekerja sama dalam menciptakan kreativitas yang baru. Sehingga antara keduanya berkomunikasi dan saling memahami agar lebih baik dalam mengembangkan kreativitas yang baru.

4. Solusi yang diberikan agar fasilitas sekolah dapat memadai ialah meningkatkan fungsi keberadaan komite sekolah yang jujur, independen, serta transparan sebagai pihak yang mengawasi kecurangan yang dilakukan oleh pemerintah daerah maupun pihak sekolah. Guru merasa kurang puas dengan pemelajaran yang dilaksanakan, solusi yang dapat diberikan ialah guru dapat meningkatkan wawasan yang berkaitan dengan pembelajaran 
yakni mengikuti program MGMP (Muyawarah Guru Mata Pelajaran) Solusi yang diberikan agar guru percaya diri dalam memberika pembelajaran ialah bahwa seorang guru tidak boleh merasa takut dan tidak percaya diri dari segi hal apapun baik ketika pembelajaran berlangsung.

\section{DAFTAR PUSTAKA}

Abdul Mujib dan Yusuf Muzdakkir.Nuansa-Nuansa Psikologi Islam. Jakarta: PT. Grafindo Persada, 2009.

Departemen Pendidikan dan Kebudayaan. Kamus BesarBahasa Indonesia. Jakarta: Balai Pustaka, 1995.

Hamid Darmadi. Metode Penelitian Pendidikan. Bandung: Alfabeta, 2011.

Kemampuan Dasar Mengajar Bandung: ALfabeta, 2012.

Iskandar Agung. Meningkatkan Kreativitas Pembelajaran Bagi Guru. Jakarta: Bestari Buana Murni, 2010.

Slameto. Belajar dan Faktor-faktor yang Mempengaruhinya. Jakarta: Rineka Cipta, 2003.

Sugiyono. Metode Penelitian Kualitatif, Kuantitatifdan R\&D. Bandung: Alfabeta, 2009.

Suharsimi Arikunto. Prosedur Penelitian Suatu Pendekatan Praktik. Jakarta: RinekaCipta, 2006.

Sukardi. Metodologi Penelitian Pendidikan: Kompetensidan Praktiknya. Jakarta: Bumi Aksara, 2003. 